\title{
Ultrawide field imaging and sonography of a radial buckle
}

\author{
Brijesh Takkar, Divya Agarwal, Hemant Kumar Joshi, Pradeep Venkatesh
}

Dr Rajendra Prasad Centre for Ophthalmic Sciences, All India Institute of Medical Sciences, New Delhi, India

\section{Correspondence to Dr Pradeep Venkatesh, venkyprao@yahoo.com}

Accepted 3 September 2017

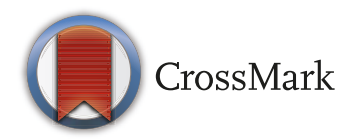

To cite: Takkar B, Agarwal $D$, Joshi HK, et al. BMJ Case Rep Published Online First: [please include Day Month Year]. doi:10.1136/bcr-2017221761

\section{DESCRIPTION}

A 78-year-old male presented with blurring of vision in right eye (RE) since 2 months. He was diagnosed to have retinal detachment in RE 27 years ago, which had been successfully repaired with scleral buckling surgery. Retinal holes had been treated with laser prophylaxis in left eye (LE). On examination, visual acuity was 6/24 in RE and 6/9 in LE. Both eyes had posterior subcapsular cataract (RE $>\mathrm{LE}$ ). The retina was attached in RE, while features of high myopia, like fundus tessellation and peripapillary crescent, were evident. Indent of a radial explant was noticeable in the inferior nasal quadrant along with indent of an encirclage band (figure 1). Lattice degeneration and adequately lasered retinal lesions were seen in both eyes. The posteriorly placed radial explant was noted as a raised and hyperechoic structure with corresponding acoustic shadow on ultrasound B scan of RE (figure 2). The patient was advised elective cataract surgery.

Scleral buckling has a high success rate for repair of retinal detachment. It may be done with implants or explants, which can be used circumferentially or radially. ${ }^{1}$ The main indication of a radial buckle has been posterior location of retinal breaks beyond the limits of support by a circumferential buckle. However, technical advances in vitreous surgery have now propelled vitrectomy as one of the primary choice procedures and radial buckles are used very uncommonly now. ${ }^{12}$

In the days when radial buckling was a commonly performed procedure, retinal imaging was not as

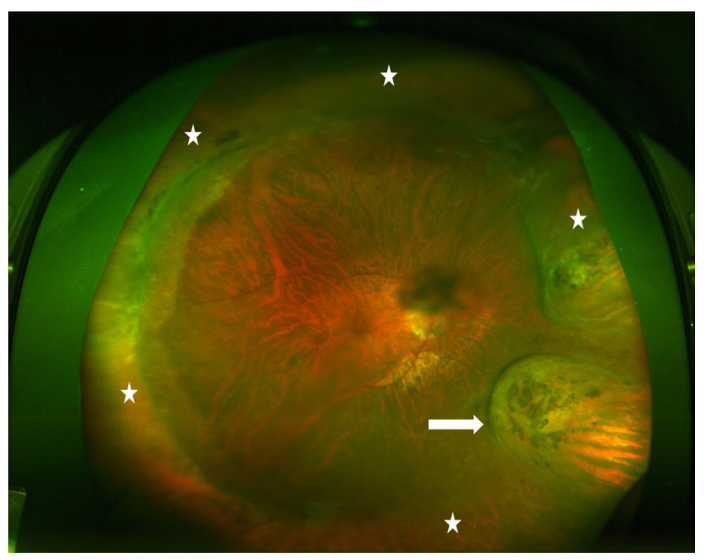

Figure 1 Ultrawide field fundus photograph of right eye. The radial buckle (arrow) is seen as a raised indent in the inferior nasal quadrant along with a circumferential encirclage (stars). Lattice degeneration can be seen in the superior temporal quadrant. Multiple lasered lesions are seen, including one over the radial buckle.

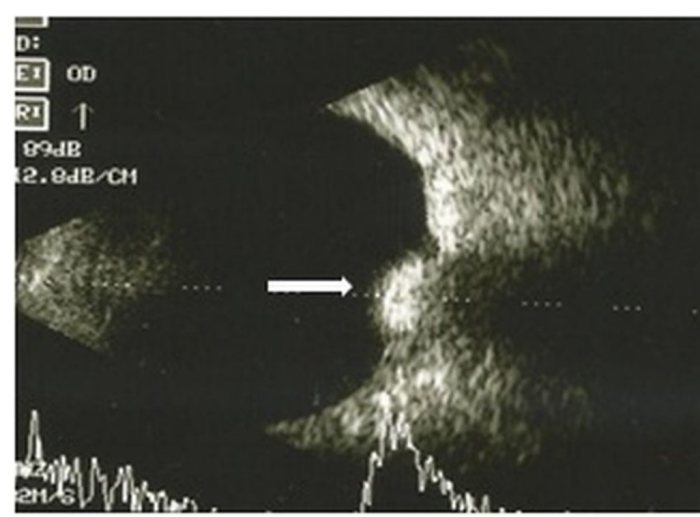

Figure 2 Ultrasound B scan with superimposed A scan showing a smoothly raised structure with indented ocular coats in the inferior-nasal quadrant. A dense acoustic shadow can be seen corresponding to the explant.

developed as today. ${ }^{3}$ Therefore, literature lacks in good wide field fundus photographs of a radial buckle which could be used for teaching new surgeons. The purpose of this imaging report is to document clinical appearance of a radial explant with ultrawide field imaging. Further, as these elements are placed posteriorly, they may be imaged during ultrasound by an unaware surgeon, who should be aware of its appearance.

\section{Learning points}

Scleral buckling with radial explant may soon become an obsolete procedure and beginner surgeons should be aware of the clinical appearance of a radial explant.

- As the radial explant is placed posteriorly, it may be imaged unintentionally by a surgeon during sonography as a raised and hyperechoic structure with smooth contour and an acoustic shadow.

Contributors BT and PV performed the workup and management of the patient. BT and DA wrote the script, BT and HJ did the imaging. PV critically revised the script and holds the overall responsibility of the article.

Competing interests None declared.

Patient consent Obtained.

Provenance and peer review Not commissioned; externally peer reviewed.

(c) BMJ Publishing Group Ltd (unless otherwise stated in the text of the article) 2017. All rights reserved. No commercial use is permitted unless otherwise expressly granted. 


\section{REFERENCES}

1 Sudhalkar A, Sudhalkar A. Scleral buckling surgery using multiple radial buckles: a valid option? Saudi J Ophthalmol 2015;29:192-6.
2 Azad SV, Takkar B. Rhegmatogenous retinal detachment. In: Basics of vitrectomy: Thieme, 2016:63-84. Chapter 6.

3 Shoughy SS, Arevalo JF, Kozak I. Update on wide- and ultra-widefield retinal imaging Indian J Ophthalmol 2015:63:575-81.

Copyright 2017 BMJ Publishing Group. All rights reserved. For permission to reuse any of this content visit

http://group.bmj.com/group/rights-licensing/permissions.

BMJ Case Report Fellows may re-use this article for personal use and teaching without any further permission.

Become a Fellow of BMJ Case Reports today and you can:

- Submit as many cases as you like

- Enjoy fast sympathetic peer review and rapid publication of accepted articles

- Access all the published articles

Re-use any of the published material for personal use and teaching without further permission

For information on Institutional Fellowships contact consortiasales@bmjgroup.com

Visit casereports.bmj.com for more articles like this and to become a Fellow 